\title{
The Benefits of Nature-based Writing for English Language Learners
}

\author{
Kiri L. Manookin \\ Department of English Language Learning, Utah Valley University, Orem, Utah, United States of America
}

\begin{abstract}
This paper explores the value of ecopedagogies and ecojustice education in an increasingly nature-deficit and attention-directed world, and does so through the lens of place-based education. More specifically, this paper explores the positive impact nature-based writing in the Department of English Language Learning at Utah Valley University (UVU) has on English language learners (ELLs). The ecopedagogical program at UVU includes multiple opportunities for conducting environmental/economic research and writing in several relevant genres, but this paper primarily focuses on qualitative data retrieved from semester-long Nature Journals and a Wilderness Writing Workshop held during a four-day department-sponsored excursion to Capitol Reef National Park in south-central Utah in the United States. The benefits of nature-based writing include greater engagement and increased desire to write, improved vocabulary and language skills, more poetic writing, less reported stress, and a greater sense of connection to all other living beings. As added benefit, English language learners at UVU have also had opportunities to participate in civic-minded conferences, have been interviewed with the author on public radio, and are expected to have work published in an upcoming anthology.
\end{abstract}

Index Terms-nature-deficit disorder, ecopedagogies, ecojustice, biophilia, place-based education, soft fascination, nature-based writing, ecospirituality

\section{INTRODUCTION}

When reflecting on his experience in the Wilderness Writing Workshop ${ }^{1}$, which the author conducted on a four-day school trip to Capitol Reef National Park, one South Korean student said in all sincerity that he really wanted to express himself in writing, specifically about his experience and how spending that time interacting with nature had impacted him personally.

For English language learners, learning to write is a necessity and not often an experience many look forward to, which makes the above story even more remarkable. However, studies show that interacting with and writing about nature have a variety of positive effects on students. Place-based writing and ecopedagogies, or pedagogies that help connect students to the natural world, may help provide additional benefits. In an increasingly nature-deficit world, then, what role does nature-based writing hold for English language learners? What are the benefits for L2 writers?

\section{LITERATURE REVIEW}

In his groundbreaking book, Last child in the woods: Saving our children from nature-deficit disorder, Richard Louv (2005) explores "the increasing divide between the young and the natural world, and the environmental, social, psychological, and spiritual implications of that change" (p. 2) and argues that in order to be healthy, creative, and in tune with the full use of their senses, children and adults need direct contact with nature. His work pivots around the question, what would it be like if nature permeated our lives in the same way technology does?

Evidence demonstrates a growing disconnect between humans in the technologically driven world and the natural world. Children and adults are increasingly sedentary and "plugged in," and the natural world is increasingly being exploited for economic profit. Yet studies repeatedly confirm the cognitive and health benefits of interacting with nature for both young and old. These benefits include lower risk of depression (Kaplan \& Berman, 2010; Louv, 2011), less stress (Williams, 2016), less fatigue (Louv, 2011), increased soft fascination and reflection (Kaplan \& Berman, 2010), increased ability to perceive connections, (Louv, 2011), increased attention and mental acuity (Kaplan, Bardwell, \& Slakter, 1993; Louv, 2011; Williams, 2016), restorative cognitive function (Williams, 2016; Louv, 2011; Kaplan \& Berman, 2010; Berman, Jonides, \& Kaplan, 2008; Kaplan, Bardwell, \& Slakter, 1993), and a greater sense of wellbeing and optimism (Marselle, Irvine, and Warber, 2014). Additionally, interacting with nature can also stimulate creativity and offer inspiration, as reported at a Danish outdoor kindergarten, where 58 percent of children created new games, as opposed to only 16 percent of kindergarteners inside (Louv, 2011).

A. Ecopedagogies and Ecojustice

\footnotetext{
${ }^{1}$ Term borrowed from McMurtrey, A. (Presenter). (1995, March). Paper presented at $45^{\text {th }}$ Annual TESOL Convention: The world as classroom: Using excursions in intensive CBI courses. New Orleans, LA.
} 
Defined by Misiaszek (2011) as "transformative environmental education which critically and dialectically deconstructs how social conflicts and environmental (socio-environmental) devastation are connected," ecopedagogies seek to connect students with nature through educational models of "social justice and radical transformation" (abstract, p. 1). Based on the ideas of philosopher Paulo Freire and an education ethic promoting social justice, sustainability, and ecoliteracy, ecopedagogies emerged in the early nineties in Latin America in an attempt to assuage an ever-growing global ecological predicament. While having roots — pun intended — in leftist political movements, ecopedagogies are simply pedagogies that help students connect to the surrounding natural world by experiencing it, thinking about it, and understanding it in ecological ways (Birrell, Gray, \& Preece, 2013). They are designed to help transform what students notice and are aware of, and how they view and interact with the natural world.

Ecopedagogies naturally help students develop a sense of ecojustice, which refers to ecology, justice, fairness, the common good, and meeting the needs of all members of society. Ecojustice also recognizes the rights of other creatures and advocates that natural systems be respected and considered in decisions. Concerned with sustainability for all, ecojustice sees humans as an integral part of the "larger living fabric of all that is" (Gibson, 2004, p. 24).

In ecopedagogies or ecojustice education, teachers work to make places, people, living creatures, and ecosystems relevant in order to help students recognize all levels of diversity within living systems and communities, especially within local contexts, and develop a sense of "place consciousness" (Gruenewald \& Smith, 2008; Lowenstein, Martusewicz, \& Voelker, 2010).

Ecopedagogies are beneficial in several ways. For example, they increase or awaken students' sense of what E. O. Wilson termed biophilia (as reported in Louv, 2011, p. 53), or having a sense of being connected to other living species, and they increase awareness of the connectivity of themselves to nature. Ecopedagogies also enhance students' creativity, develop a sense of responsibility to the Earth's environment and peoples, and help students see the direct impact of human interaction in order to take responsibility for their own impact (Birrell, Gray, \& Preece, 2012). All of these educational outcomes together have the potential for creating a serious shift in how humans interact with, use, abuse, or manage natural resources.

\section{B. Place-based Education}

Place-based, or place-conscious, education, purposefully sets teaching and learning in a particular "pedagogically fruitful" location, and acts to connect the global to the local since having a sense of place is so often directly linked to one's cultural, physical, or emotional identity (Semken \& Brandt, 2010). Places, argue Semken and Brandt (2010),

are where we sense and connect to our natural and cultural surroundings, and sense of place is a construct that usefully describes this connection. Place-based education... is highly relevant to environmental ethics, conservation, ecological integrity, and cultural sustainability, because all of these are also situated in places. (p. 289)

Semken and Brandt (2010) also recommend that teachers acknowledge and expertly "leverage" the senses of places students bring with them. This is particularly important for teachers of English Language Learners (ELLs) to do. For example, a student from the jungles of Ecuador, where big oil companies have control over resources and cause devastating ecological and economic damage to the surrounding native communities, and a student from the Arabian peninsula, where oil exportations drive and sustain the economy, may differ in their environmental ethics, their ideas about ecological integrity and cultural sustainability, and their approach to conservation due to their individual identities tied to place (Semken \& Brandt, 2010).

Ecological place-based education is characterized in several distinct ways: 1) it emerges from the specific features of a place; 2) it is multidisciplinary; 3) it is inherently based on experience and observation; 4) the motivation for learning goes beyond just "earning"; and 5) it helps connect place, self, and community (Gruenewald, 2003). Pedagogies like this are crucial in order to directly connect education to the health and well being of people and the places where they live. For adult English language learners, this type of education can be especially beneficial because these learners are often coming from one place to another with intact identities tied to both places.

\section{Attention}

Without interaction with nature, however, people's abilities can be diminished. Louv (2011) cautions: "We cannot protect something we do not love, we cannot love what we do not know, and we cannot know what we do not see. Or hear. Or sense" (p. 104). Several military studies have demonstrated that soldiers who are far better at being able to notice bombs in the field, or "bomb-spotters," have grown up "outside the electronic bubble" and in direct rural contact with nature or in urban often-gang-ruled neighborhoods where observing territories is crucial because they have more highly developed powers of observation and discernment (Louv, 2011, p. 17). Soldiers who have grown up playing video games or without much contact with the outside world, "lacked the ability to see nuances...that combination of depth perception, peripheral vision, and instinct, if you will, to see what was out of place," the kind of observation that might tip one off to a road-side bomb (Louv, 2011, p. 17). These gamers perceived their view through a Humvee windshield like a computer screen, rather than one part of the complete environment.

Likewise, diminished skills due to a lack of interaction with nature may prove to be doubly disadvantageous for the general public: without it, we may literally not be able to recognize nature's wonder or need. 
The powers of observation of ELLs may also be somewhat culturally dependent. Depending on where they are coming from, many students may have abundant experience with digital media and very little with the natural world, and their powers of observation in other circumstances may be diminished.

In discussing diminished powers of observation, Kaplan and Berman (2010) report on two types of attention. Involuntary attention is a kind of "automatically activated" interest in strange, moving, or bright things — like seeing an animal in the wild. Voluntary attention, also referred to as directed attention, in contrast, is the kind of goal-oriented attention that requires quite a bit of effort and is not automatic (p. 46). Kaplan and Berman (2010) argue that one's directed attention is often elicited with far more demand than it is capable of. Some refer to this condition as directed attention fatigue (Kaplan, Bardwell, \& Slakter, 1993); others refer to the same sort of condition as continuous partial attention, or not wanting to miss anything and paying partial attention to many things continuously, which results in a sense of being "always-on, anywhere, anytime...[and experiencing] an artificial sense of constant crisis" (Stone, 2002-2010). While these two conditions may be distinct in a couple of ways, the impact of them is the same: the ability to fully focus is lost, and this diminished attention manifests itself in friendships, relationships, and the relationship to one's surroundings.

Because the demands on the directed attention of English language learners are, at times, enormous, their ability to focus is often shortened or diminished, and their motivation for learning or practicing language is reduced. As Crossley and McNamara (2011) explain, ELLs experience the frequent challenge of not having automatized lower-level writing skills like L1 writers have, who pay little conscious attention to lexical and syntactic decisions and can therefore allocate far more focus to higher-level skills like organization. Having to pay far more attention to lower-level strategies may influence students' metacognition and experience with writing in the past, which may, obviously, affect writing quality because of fewer options in language (Crossley and McNamara, 2011).

In the case of directed attention fatigue in English language learners, an intervention must be made in order to help give them a chance to effectively rest their directed attention so they can learn more successfully and enjoyably.

One approach is the Attention Restoration Theory (ART), built on the premise that directed attention needs to be allowed to rest through interaction with nature (Kaplan \& Berman, 2010). "The Kaplans [environmental psychologists Rachel and Stephen]," explains Louv (2011),

hypothesize that the best antidote to such fatigue, which is brought on by too much directed attention, is involuntary attention, what they call "fascination," which occurs when we are in an environment that fulfills certain criteria: the setting must transport the person away from their day-to-day routine, provide a sense of fascination, a feeling of extent (enough available space to allow exploration), and some compatibility with a person's expectations for the environment being explored. Furthermore, they have found that the natural world is a particularly effective place for the human brain to overcome mental fatigue, to be restored. (p. 28)

This idea of fascination is delineated into two distinguishable types: soft fascination, like the kind of attention captured by a garden, landscape, sunset, or painting, and hard fascination, the kind of attention captured by watching violence, competitive sports, or sex (Kaplan \& Berman, 2010). Soft fascination is the kind of attention that is most restful because it allows for reflective thought in a way that hard fascination does not. Kaplan and Berman (2010) imply a connection between soft fascination and the therapeutic aspects of writing.

\section{Methodology}

Blending Content-based Instruction (CBI), Project-based Learning (PBL), and a genre-based approach to writing to explore issues of sustainability, resource management, and ecojustice, the upper-level ecopedagogical English language learning program at Utah Valley University (UVU) gives students from diverse ethnic and linguistic backgrounds an opportunity to engage in identifying serious problems within a variety of ecosystems, analyzing the causes and effects of these problems, and spend time in nature responding through writing. The program includes research projects about environmental/economic issues including a Nature Journal, an oral presentation, a public awareness poster, and a researched civic report. It culminates in a four-day excursion to UVU's field station in Capitol Reef National Park for intensive language application and a wilderness experience, including a Wilderness Writing Workshop conducted by the author. This combined work comprises significant time writing about students' observations in and about nature in a synthesis of both analytical and subjective ways - and, with any luck, in a relaxed state of soft fascination.

Samples from the Nature Journals and the Wilderness Writing Workshop will be the main focus of this paper.

\section{A. Nature Journals}

Students are given Nature Journals to work on throughout the semester by spending 30 minutes observing and writing in a place of their choice. Several entries have specific prompts to respond to while others allow for freewriting (see Appendix A).

In order to give students a greater opportunity to rest their directed attention (Kaplan \& Berman, 2010) dependence on technology, most entries are to be handwritten in notebooks created by the instructor. These notebooks with the appropriate prompts are given to students who may also include drawings or other artwork, if desired. The location for nature journaling chosen by students need to be specific: the setting needs to be different from students' day-to-day routine; it needs to have a certain level of interest; there must be space and other things to explore; and it needs to be a 
place that can fulfill the expectations of the person exploring (Louv, 2011). One additional criterion is that the setting has few other human distractions.

\section{B. Wilderness Writing Workshop}

During the excursion to Capitol Reef National Park and using the observational skills they have been developing all semester, English language learners are asked to synthesize the content they have been studying with their personal experience and observations on the trip through writing, specifically in response to this prompt from Terry Tempest Williams' (1994) An Unspoken Hunger:

An echo is a sound wave that bounces back, or is reflected from, a large hard surface like the face of a cliff, or the flanks of a mountain, or the interior of a cave. To hear an echo, one must be at least seventeen meters or fifty-six feet away from the reflecting surface.

Echos are real - not imaginary.

We call out - and the land calls back. It is our interaction with the ecosystem; the Echo System.

We understand it intellectually.

We respond to it emotionally - joyously.

...We call to the land — and the land calls back.

Echo System. (pp. 82, 87)

Students are then given several opportunities to spread out and write: in situ while hiking on a trail; at the Capitol Reef Field Station where they stay; and after returning home to complete, edit, and polish their work. Semester after semester, spending time in a stunning wilderness area like Capitol Reef National Park markedly changes the way students perceive and experience the natural world and the way they engage in the writing process. When the schedule permits during the trip, participants are given an opportunity to share their writing with others. Later at home, the author compiles students' written work with images from the trip (and video and audio for ebook format) into a booklet for all participants to enjoy (see Appendix B; additional examples may be viewed by contacting the author). These materials created from students' writing act as literary souvenirs and help boost students' confidence in their English writing skills.

\section{THE FINDINGS}

Several years of qualitative research demonstrate a multitude of benefits for English language learners, as seen in the examples below. What emerges from students' nature-based writing includes:

- Increased motivation and language skill, particularly in writing

- Greater use of vocabulary

- More descriptive, even poetic, language

- Less reported stress

- Smaller linguistic gap between L1 and L2

- Common themes like relaxation and "ecospirituality" (Goulah, 2011).

Linguistically and affectively, ELL students clearly benefit from nature-based writing. Their engagement and sense of place provide powerful motivation and a relevancy to utilize the language skills they have and develop them further in order to say what it is they want to say whether that includes using vocabulary from the content or finding ways to say in English what they already know in their L1. Students report feeling less stressed and more inspired by the experience, but their writing also shows them taking more risks in language by using more poetic language and structures, which indicates a more flexible, investigative, and sometimes even playful approach to using language. By all indications, the gap between L1 and L2 narrows - one student even reported the joy of being able to think in English instead of relying on translating from L1.

Most powerfully and harking back to a sense of biophilia, or a sense of connection to all living things, ecospirituality (Goulah, 2011) is consistently the most common theme woven throughout students' writing. Ecospirituality involves three main notions: understanding oneself as a member of different layers of community (the universe, the earth, animals, humans); something O'Sullivan (1999, as quoted in Goulah) refers to as "deep interiority... which allows us to appreciate deep interiority equally in all creation"; and the valuing of "diversity in secular and non-secular spiritual practices and beliefs... [that] cultivate knowledge about and appreciation for diversity of spiritual expressions" (p. 30). As seen throughout their writing, the majority of students experience these moments of awareness and connection - of realizing their place in the universe or contemplating the big questions of life; of describing being tutored by the earth, stars, plants, or animals; of reflecting on their lives and how to live them better; of being moved in their deep interiorities by the intelligence and power of the natural world and wanting to nurture it; and of recognizing and appreciating the connected onion-like rings of their community. The experience and sense of ecospirituality is evident throughout students' written experience but always preceded by and attributed to meaningful interaction with nature.

\section{STUDENT WRITING EXAMPLES}


The examples below primarily include entries from Nature Journals, the Wilderness Writing Workshop, and questionnaires, but they are additionally informed by students' nature-based work in presentations, posters, and research papers. As expected, there are some lexical and syntactic errors throughout the writing because students are still relying on their L1 to fill in the linguistic gaps of L2 (Crossley \& McNamara, 2011). However, most written entries demonstrate a closing gap and a higher level of vocabulary, even poetic language, that is detailed, insightful, heartwarming, and even occasionally amusing.

- "...In front of me, there is the whole history of millions of Earth years. It is impressive that in one place I can see different layers of land created a long, long time ago. Millions of years! It looks so steady and powerful, but at the same time the waterpockets make it look weak and fragile. The place is covered in silence, and only the strong wind sometimes threatens to ruin the quiet.

"Standing on the 200-million-year-old rock inspires me and makes me wonder about the future because I am one of the creatures who lives on this planet now. I am the next layer. I am the new generation that can make a difference on the planet, and all the previous layers are like grandpas for the younger ones. They carry history, wisdom, experience, failures, and successes. They help us understand the world before our appearance on the planet. They teach us how to appreciate simple things and fill our lives with peace and love.

"Long after this generation is gone, what is the Earth going to look like in 200 million years? Here I can see that time flows really slowly: a thin layer of cliff is a long period of time. After seeing the variety of layers and the immense contrast between them, sand lithification, and thousand-year-old cryptobiotic microorganisms, nothing seems impossible! I feel young and am inspired and ready to be part of the great future :)"

- "...The land is calling me to forget my bad emotions, the bad feelings that I am hiding inside somewhere in my body. It seems surreal because even in the daylight, the light seems to emanate from the ground through the water, glowingly flowing, and reaching all my sensation. The sound that the water is releasing acts like a refresher to my brain, making me feel new. Actually, it is sunny, and it is incredible because my body no longer hurts being on that warm rock. Generally, I do not like the sun because it hurts, but here my body is more exhilarated and comfortable, and it wants me to stay longer.

"Nature is a place where I can relax my body. Nature is what my body is seeking for. Nature is everything that surrounds humans. Nature is like a mother giving life to a baby. Humans cannot live without nature because it is the source of how we live. We live by breathing the air, drinking water, and eating foods provided by the environment. All this innocent nature exists, and staying around it is making my body magnetized to the ground.

"...Here, in this nature, I no longer envy modernity. In this natural world it is different. I do not want more but less."

- "...I enjoy...nature now, and I can look around and can see how beautiful the world [is]. I have no rush to live, and I love when you [Kiri] tell us to take a breath. I am relaxed. I feel free. I feel alive. I feel in connection with nature. Yeah, it's changed [desire to write]...you feel more concentrated, like your feelings wake up to write."

- "Here is a land of rest.

“...In a moment, I do not hear anything, but this "anything" does not mean "nothing," it is a muted song from trees, cryptobiotic soil, sand, plants, lichen on rocks and the waterpocket fold.

“...The difference between here and the city is 'awareness,' 'true love,' 'enormity.' Awareness because we know who and where we are. True love because we cannot anymore fool ourselves here and lie to nature. Enormity not because of its magnitude but because of its richness, power, and value. Everything here is natural, and nobody can play the fool. Here, I can no longer be unsatisfied by who I am because my soul belongs to the ground.

"I am falling in love with this environment...I envy these trees and stumps...

"I guess it is true that when you are under the sun, you want the cold shadow, and when you have the cold shadow, you want the sun. ...Here, in this nature, I no longer envy modernity. In this natural world it is different. I do not want more but less.

"The trail here intrigues me and seduces me to go deeper like a baby in front of candy. At first glance, the volcanic rocks look simple like the regular rocks, but through my connections with nature I realize they are not just beautiful, but special, atypical, and incredible.

"Everyone who can understand nature knows the true meaning of life.

"Here is a natural world."

- "I [was] impressed..., so that made me want to write something. It was easy to write...because I love that."

- "When I saw some pretty view or heard nature sounds, I can open my thinking.... Inspired. That's how I feel."

- "When we were in Capitol Reef looking at the sky, our minds explode[d] with imagination."

- "I feel more engaged and interested in writing in English."

- "I've got new thoughts and new vocabulary."

- "...between these trees, I feel safe."

- "I also realized why the sand is so much softer than other types of ground: because the wall of sand fell to the ground."

- "We had to help each other to cross the valley hand in hand." 
- "I remember listening to the wind breaking on the rocks, and the purity of it made me think about the damage that we are causing to our own home. If we could have the same quality of air and the calm of this place everywhere in the world, it would be different."

- "While I was hiking, my two little eyes were looking around all the time; I looked 360 degrees around me, no more screen watching. It was a few days that I live without social network and I loved it! I could be with the nature and with my classmates; we talked and knew more about each other. And one thing that I like the most...when we were eating dinner no phone playing like we used to..."

- "Oddly enough, I always felt less tired after hiking."

- [About the Milky Way] "It looked like when you made a way with salt in a black carpet...I saw a galaxy, it looked like millions of tiny luminous points...stars were fireflies that got stuck..."

- "The sky is super freaking blue. When you see the sky, you want to swim, drink, walk, or just stay in it forever."

- "The sky was a mixture of dark midnight blues and purples. The stars were sparkling and gorgeous. They decorated the sky magnificently."

- "The million stars formed a Milky Way that look[ed] like a long chiffon fluttering on the dark night sky."

- "That place has power to refill your soul."

- "Now we have made a stop in a phenomenal place only to write, to express our emotions based in some questions that our teacher left us, but with or without the questions my mind is flying, imagining all the stories that this place keeps. 'If the rocks could speak,' I think, 'how much more could we learn and understand?' If I close my eyes I have the strong sensation of being at the beach. The sun is so warm, the wind, the salty smell and flavor, the sand. Every one of the things mentioned are the components of the beach except when I open the eyes and I see a desert, I have the sensation that a long time ago this place was an ocean, and only God knows the reasons the water gone. This is really awesome. ... Without a doubt, life here is not easy, especially as the need of an element so appreciated as water. Every plant, rock, animal looks designed for protection... in my mind appears another idea as 'Nature is very smart,' because they try to protect themselves and not be the food for another species. I was lucky to see some animals here such as birds, a black and white caterpillar, red ants, goats, some deer, and a chipmunk. I know that there are a lot of animals here, but maybe the place is so humongous that it is not easy to see them. I can only say now that I am happy to be here. I feel like part of a big book that tells the story of ancient people, and it is better to be alone with myself, far away from technology, noise, worries and all the other things that are part of our lives."

- "While I was hiking, I used my five senses for feeling nature. First of all, I could smell the sun and sand. Winter was coming, but this desert let me feel summer air. Second, I saw only one little purple flower in the desert. Since I entered the desert, I saw just orange, brown, and white, which are the colors of the sand, so the flower looked very vivid and bright to me. When I saw it, I felt I found something special. Next, I heard a bee's humming. I usually do not like these sounds because I think the bee will try to attack me. However, I did not feel any fear this time; I just felt their lives. Their humming is same as our breathing, so I did not need to feel fear since I changed my mind. Also, I heard 'quiet.' I could feel this sound, especially when students were talking. I could hear clearly what they were talking about. In my life, everything is filled with a lot of noise pollution, so this moment was the most quiet moment in my life. When I heard quiet, and I was quiet, I realized that I was part of nature at that time. Finally, I saw real adaptation plant during hiking. The plant was Utah Juniper which has white nuts and white stem. At first, I did not know why it was white, but it was one kind of adaptation. The white color is for protecting from strong sunshine. Even if the plant cannot move like us, I can feel that they really want to live there, so they change themselves. I was amazed to this plant's power. It looked weaker than a human, but it can adapt in ways humans cannot do."

- "...[Like an echo,] you get what you give, so when you are kind to a person this person will be kind with you. Likewise, this principle works for the relation between humans and nature; if people show kindness to the nature, nature will be in balance. However, if we destroy the ecosystem...nature is going to destroy us."

- "I think that they [birds] are happy here, free of [the] haunt [of] man."

- "I am really grateful for this trip, really grateful, because it is the first time that I realized the importance of being connected with the environment. I could live and understand our world differently, now I feel I am more aware about taking care of nature and trying to avoid every type of pollution, because the Earth is our home, and it is the house that we are going to leave for our next generation."

- "I love it! Before I did this homework, I didn't want to do, but I felt positive feeling since I entered nature."

- "I felt peace, energy, and happiness. I noticed more things around me that inspired me to write about [what] my senses feel."

- "I began to think about stories that I have ever heard or read to connect them in one idea."

- "I saw more details that helped me describe the environment."

- "I feel more engaged and interested in writing in English."

- "It was really hard but I notice my writing skills improve."

- "Nature makes us think deeper."

- "I just want to say I needed more time..."

- "Walking here in this lonely but exciting place, it was a great sensation. I felt things I didn't think I would be able to feel.... However, this place did its magic." 


\section{DISCUSSION}

Observationally as a writing instructor, it is safe to assume that the majority of students entering class every semester - so often as what can only be called "technology junkies" - are not terribly excited to be there. They are likely low in motivation to write and do research because they know - either from experience or from a lack of experience - that writing, especially academic writing, can be challenging. They come from various cultural and literary backgrounds with differing attitudes toward the natural world and the use of written language for reading and writing purposes, and with an understanding of different rhetorical structures for writing. They also come with a variety of educational backgrounds and academic exposure. Stress levels, and therefore affective filters, are often high, and students' ability to focus can easily disintegrate. More often than not, the majority of English language learners entering writing class reportedly come with a sense of dread at what could be coming. However, students most often experience a fundamental change in academic engagement, opinions, and attitudes, and often go from disliking or feeling stressed about writing to enjoying or even loving it and understanding its potential power. It is evident in the above examples how deeply students are affected by this ecopedagogical connection to place, both in academic and personal ways. Ecologically focused content and direct contact with nature inform students' approach to environmental issues, as well as help improve their writing skills and feel better about the writing process.

Through this nature-based writing, English learners at UVU have also experienced increased opportunity for local civic and academic involvement in several ways.

- English language learners have participated in the annual Conference on Writing for Social Change at UVU where they have an opportunity to share their nature-based research in a poster session for a university-wide audience.

- In honor of Earth Day in April 2017, several students along with the author were interviewed by Tom Williams, host of Access Utah, a public radio show (http://upr.org/post/earth-day-thursdays-access-utah) about how young people are responding to land and environmental issues through writing (Williams, 2017). Appropriately, the live interview was conducted from the field station at Capitol Reef National Park just as students were participating in the Wilderness Writing Workshop.

- As a result of participating in the Wilderness Writing Workshop during the excursion to Capitol Reef National Park, written work from several students is to be published in an upcoming anthology about Capitol Reef National Park (anticipated in 2019).

Each of these opportunities makes writing more relevant in local and more expansive contexts, and ups the engagement and perceived responsibility students have for their work. Combined with increased awareness and personal insight, opportunities like these create greater engagement in the local community that can be especially important for L2 writers who run the risk of being disengaged and/or isolated while studying English in communities not their own.

\section{IMPLICATIONS AND SUGGESTIONS FOR FUTURE RESEARCH}

The following are ideas for some future implementation and research:

- Per students' frequent request (like music to a writing teacher's ears), spend more time in nature and more time writing

- Find additional opportunities to publish student writing

- Increase student participation in local civic-minded and/or environmental issues by having students write advocate letters, letters to the editor, op-ed pieces in campus or local newspapers - this could help connect ELLs to the local context of the broader community, enrich the lives and expand the understanding of other community members, and help ELL students understand the value of their voice

- Encourage students to join local campaigns or organizations dedicated to creating social change

- Create a class blog or website to showcase student research and writing

- Create reading circles in and out of class

- Guide students in not only writing during the workshop but also in compiling, designing, and publishing the book. This would take some serious logistical choreography, and may only be appropriate for certain classes of English language learners.

\section{CONCLUSION}

In conclusion, English language learners benefit greatly from participating in nature-based writing. Students often develop a better, less stressful relationship to writing. They feel more engaged and motivated in their work, experience increased soft fascination and greater awareness, and develop better language skills. Finally, inspired, taught, and humbled by the natural world, they experience a sense of biophilia and ecojustice and recognize their connection to and place in the natural world. Simply put, L2 writers benefit both academically and personally, and engage more in writing in English, when interacting with nature. Nature-based writing founded on place-based ecopedagogies can be extremely powerful and engaging, and in many ways, as several students recount, instructors simply need to let that experience work its magic. 
APPENDiX A. NATURE JOURNAL

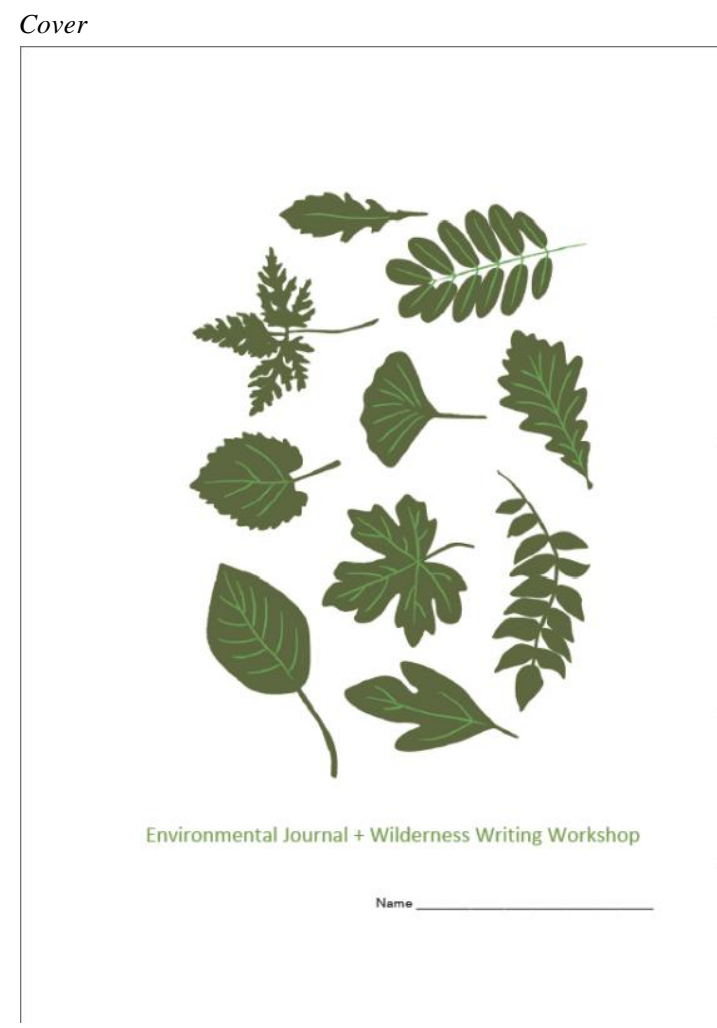

Introduction Page

\section{Writing Prompts}

Prompt: Pay attention to how you feel being in nature. Describe your feelings. Do you notice an emotional response? Have you ever had an emotional response to interacting with nature? Explain in detail.

Prompt: "Silence is not the absence of something, but the presence of everything." -Gordon Hempton, Founder of One Square Inch of Silence

(Taken from the website http://onesquareinch.org/):

"One Square Inch of Silence is very possibly the quietest place in the United States. It is an independent research project located in the Hoh Rain Forest of Olympic National Park, which is one of the most pristine, untouched, and ecologically diverse environments in the United States. If nothing is done to preserve and protect this quiet place from human noise intrusions, natural quiet may be non-existent in our world in the next 10 years. Silence is a part of our human nature, which can no longer be heard by most people. Close your eyes and listen for only a few seconds to the world you live in, and you will hear this lack of true quiet, of silence. Refrigerators, air conditioning systems, and airplanes are a few of the things that have become part of the ambient sound and prevent us from listening to the natural sounds of our environment. It is our birthright to listen, quietly and undisturbed, to the natural environment and take whatever meanings we may from it. By listening to natural silence, we feel connected to the land, to our evolutionary past, and to ourselves. One Square Inch of Silence is in danger, unprotected by policies of the National Park Service, or supported by adequate laws. Our hope is that by listening to natural silence, it will help people to become true listeners to their environment, and help us protect one of the most important and endangered resources on the planet, silence."

Go to any place of your choice, but especially one where you can really focus on one square meter of ground. Watch, look - really look - observe, listen, touch, feel, and study that one square meter for your whole practice and write about your experience.

Prompt: "The term plant blindness was coined by James Wandersee, of Louisiana State University, and Elisabeth E. Schussler of Southeastern Natural Sciences Academy. In an article for Plant Science Bulletin (published quarterly by the Botanical Society of America), they define plant blindness forthrightly, as 'the inability to see or notice the plants in one's own environment.'... One of the reasons may be the inherent constraints of our visual information processing systems. 'It seems that visual consciousness is like a spotlight, not a floodlight,' they write" (Louv, 2011, pp. 105-106, original italics).

Now that you have been spending time outside in nature, have you become aware of any plant blindness on your part, or any change in your ability to see and notice things in your environment? What do you think is meant by the statement, "It seems that visual consciousness is like a spotlight, not a floodlight"? What does that mean for you?

Prompt: What is an echo? Have you ever heard one? If so, where? Have you ever created one yourself? If so, explain. If not, explain what you understand about echoes and how they work. Write as much detail as you can. 
APPENDIX B. WILDERNESS WRITING WORKSHOP

\section{Booklet Cover Examples}

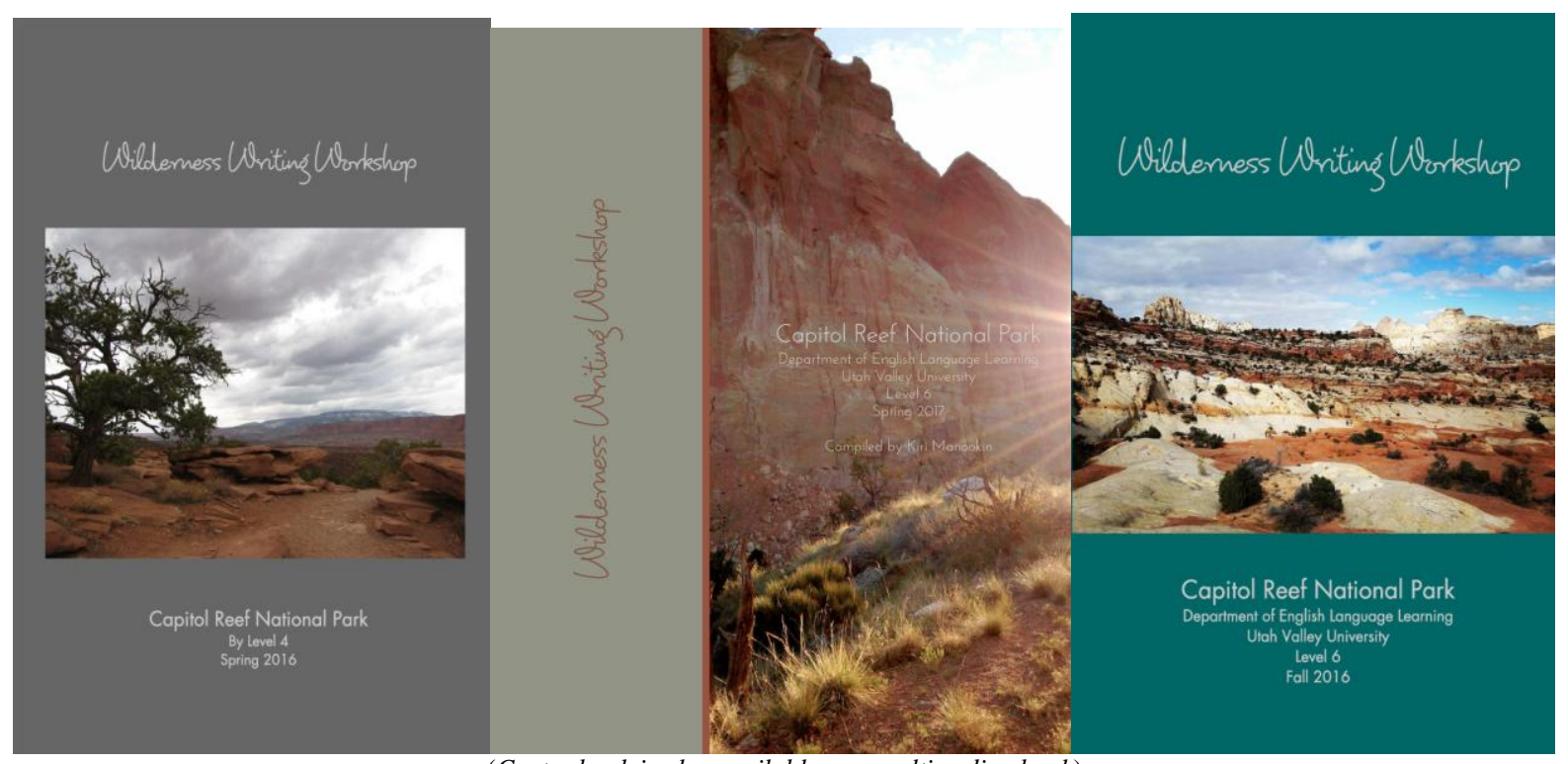

(Center book is also available as a multimedia ebook)

\section{Introduction Page}

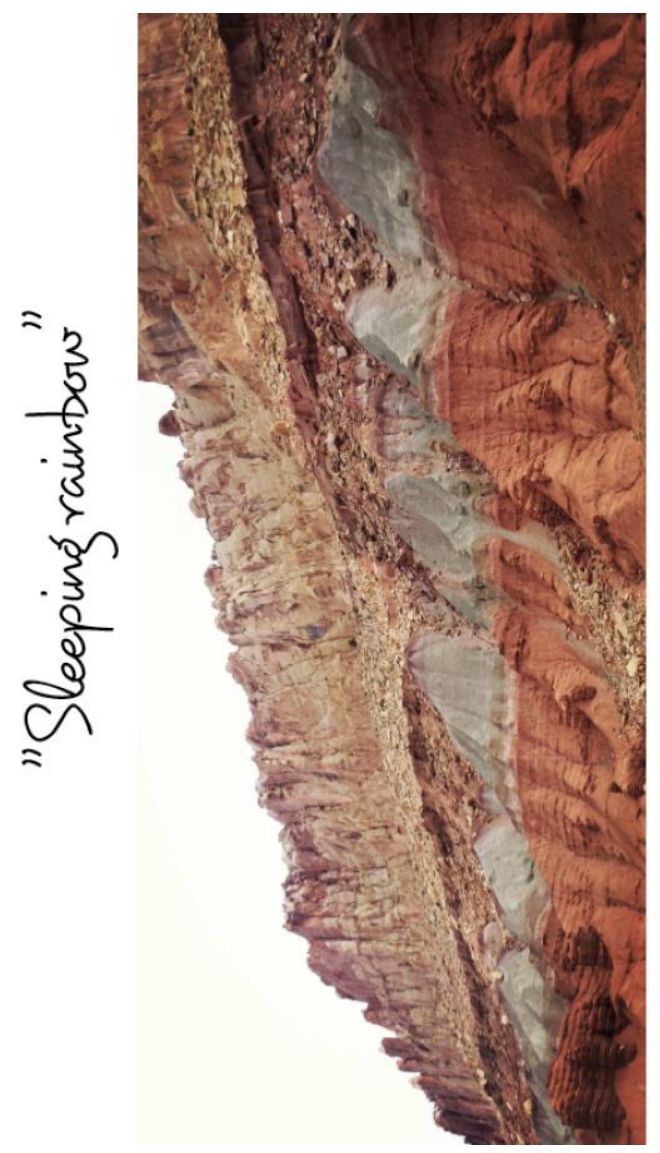

$$
\text { Wilderness Writing Workshop }
$$

The following essays were written during a Wilderness Writing Workshop held on an overnight school trip to Capitol Reef National Park in southeastern Utah. The park's "main claim to fame," as Chip Ward (1999) writes in Canaries on the Rim, is

its colorful geology especially the multicolored layers of rock... Spires and domes of white Navajo sandstone sit on top of big broken red walls. Layers of chocolate Moenkopi and paste mounds of vide, lor wis phe and gray ash follow boneath. The Navojo name for this phenomenon translates as "sleepin rainbow." (p. 4 )

Millions of years of earth history that would otherwise be locked away underground are discernably tangible in this geologic wonderland.

Non-native English-speaking students were asked to write about their experience on the trip and to respond to the following from Terry

We call out-and the land calls back. It is our interaction with the ecosystem; the Echo System.

We understand it infellectually.

We respond to it emotionally-joyously.
We call to the land-and the land calls back.

Echo System. (pp. 82, 87)

What follows represents several hours of quiet reflection and writing What follows represents several hours of quiet reflection and writing,
plus their own editing. Only the spacing has been altered for formatting plus their own editing. Only the spacing has been altered for formatting
purposes.

As their writing instructor, I am delighted by the surprising articulation of thoughs and leelings, and the way that the experience in

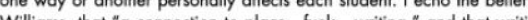
"Wective

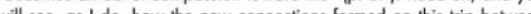
human and earth and the heavens inspired this group of students, and you will sense in them a greater compassion for life.

-Kiri Manookin, Fall 2016 


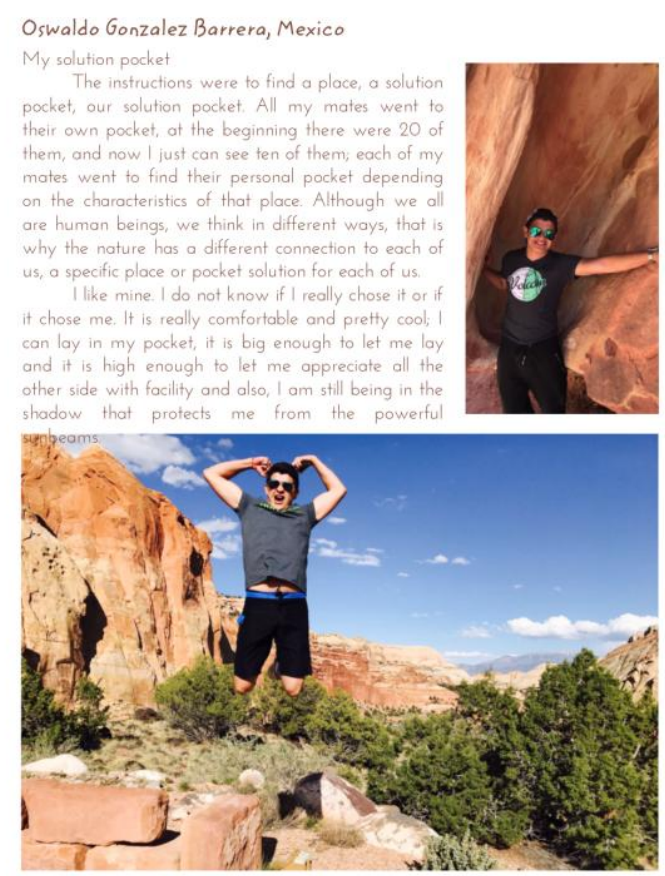

26
Iryna Chelepis, Ukraine

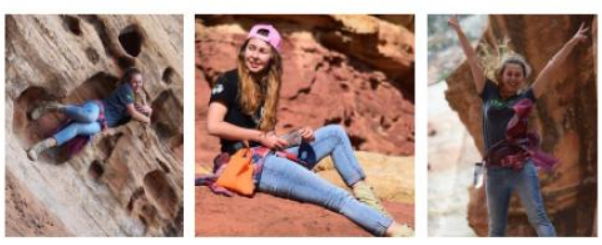

Sometimes the speed of our lives doesn't give us a chance to enjoy living in such a wonderful world. Capitol Reef National Park is one of those places where everything goes slower and faster at the same time. Our school trip there was the most unforgettable, breathtaking, and amazing experience of my first semester here in USA.

181 miles to Capitol Reef flow very fast with interesting conversations, awesome landscapes, wonderful stories, and a big cup of fresh black coffee in my hands. We spent four incredible and unbelievable sunrises and sunsets of our lives in Capitol Reef Field Station. Those five days showed us the value of natural resources and the true cost of our noisy existence in marvelous world. This little journey helped us to build strong connections inside the class and with nature. Here, thanks to an absence of phone signal, I first talked to some of my classmates, and opened up to them from completely to some of my classmates, and opened up to them from completely new side. We played games logether, lived together, ate together, sometimes even shared the bohroom logeher. We became more than friends; we became an international family. We found two new dads, three moms, one young aunt, and 18 siblings, the best brothers and sisters in the

We hiked a lot during that week, and my favorite hike was last one, to the Hickman Bridge. It taught us to work as one team, one organism, to give a hand to each other in the hardest corner, and never leave anybody who needed help.

Nobody knows his or her roads of life, we never know where we'll be tomorrow, but memories about this trip will live with us and warm us up on the rainiest days. I am happy to share such wonderful moments of my life with you, my classmates, my friends, my support.

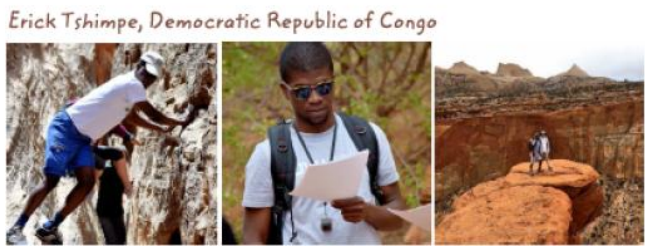

Sometimes the speed of our lives doesn't give us a chance to enjoy living in such a wonderful world. Capitol Reef National Park is one of those places where everything goes slower and faster at the same time. Our school trip there was the most unforgettable, breathtaking, and amazing experience of my first semester here in USA.

181 miles to Capitol Reef flow very fast with interesting conversations, awesome landscapes, wonderful stories, and a big cup of fresh black coffee in my hands. We spent four incredible and unbelievable sunrises and sunsets of our lives in Capitol Reef Field Station. Those five days showed us the value of natural resources and the true cost of our noisy existence in marvelous world. This little journey helped us to build strong connections inside the class and with nature. Here, thanks to an absence of phone signal, I first talked to some of my classmates, and opened up to them from completely new side. We played games together, lived together, ate together, sometimes even shared the bathroom together. We became more than friends; we became an international family. We found two new dads, three moms, one young aunt, and 18 siblings, the best brothers and sisters in the world.

We hiked a lot during that week, and my favorite hike was lost one, to the Hickman Bridge. It taught us to work as one team, one organism, to give a hand to each other in the hardest corner, and never leave anybody who needed help.

Nobody knows his or her roads of life, we never know where we'll be tomorrow, but memories about this trip will live with us and warm us up on the rainiest days. I am happy to share such wonderful moments of my life with you, my classmates, my friends, my support.
Personal feeling of wilderness

I am so excited to be here in this National Park called Capitol Reef, which is from the world. Moreover, it clears my brain and helps me think deeply can say that it is such a wonderful Area and calm. There are several things that make me feel good and comfortable like the trees, Rocks, the sounds of coming from water and the birdsong. It is totally different from the world out there

On the night of April 18, 2017, after being in our class, we went to see the such a great time being out at that time of the night. Honestly speaking, I have never seen such a dark night all my life as the one I saw that night. Seriously I close by ploce we stood becouse we turned off all the light. Something special happened to me that night at Capitol Reef Field Station, I stood outside dorm and started to make wishes for myself and started to ask the heaven to help me realize what I had on my mind; I know it is sounds crazy, but sometimes tha thing happen I felt something new inside of me and start to ask for help I tought was obout to become a crazy but not that was just a feeling

The wilderness is so important for a human even for someone's life. Researchers have proved that most people who spend time in the wilderness have a chance and the opportunity to be connected to nature and to be disconnected from the world. This is especialy a good suggestion for students and young people cellphones and computer I know how distracting it is and how it makes your brain an amazing place to be especially because of the fact that I am disconnected

have had a chance to walk in a few places since arriving in Copitol Reef. beauty of the sky with all our teachers and also feel the fresh air to night we had can remember of my country where I was able to see stars and the sky to night but that one was different and it was completely dark they were even no light 

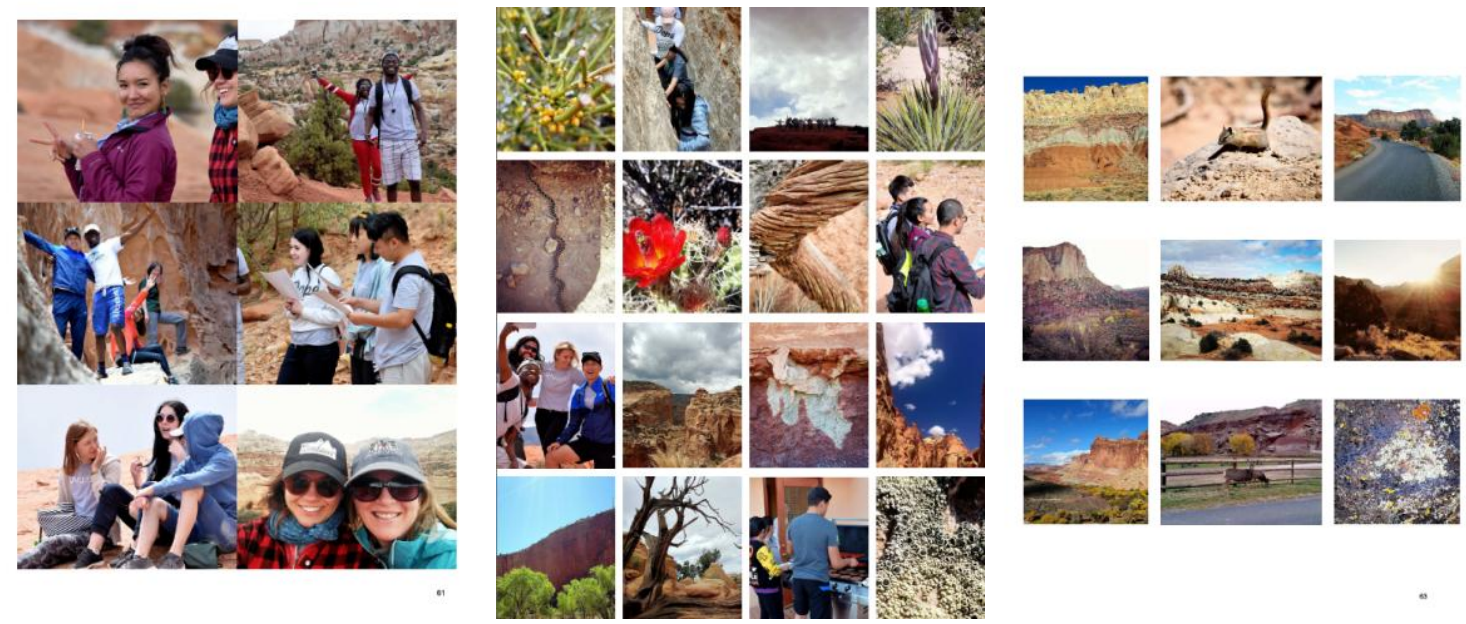

\section{ACKNOWLEDGMENTS}

The author wishes to thank her colleagues Brian MacKay, Kevin Eyraud, and Brooke Bailey for the opportunity to work with them in this ecopedagogical language program. She also wishes to thank her wonderful students who allowed the experience of writing to change them.

\section{REFERENCES}

[1] Birrell, C., Gray, T., \& Preece, M. (2013). Ecopedagogies: Ways of connecting with the natural world through the arts. Linking Art and the Environment: Proceedings of the first EcoArts Australis Conference, 2013, EcoArts Australis Inc. Retrieved from https://www.academia.edu/8370724/Birrell_C._Gray_T._et_al._2013_._Ecopedagogies_Ways_of_Connecting_with_the_Natur al_World_through_the_Arts._Linking_Art_and_the_Environment_Proceedings_of_the_first_EcoArts_Australis_Conference_2 013 EcoArts_Australis_Inc. ISBN_978-0-9924107-0-4_pp_99-105 (accessed 21/10/2014).

[2] Crossley, S. A., \& McNamara, D. S. (2011). Shared features of L2 writing: Intergroup homogeneity and text classification. Journal of Second Language Writing, 20(2011), 271-285. DOI: 10.1016/j.jslw.2011.05.007.

[3] Gibson, W. E. [Ed.] (2004). Eco-justice: The unfinished journey. Albany, NY: State University of New York Press.

[4] Goulah, J. (2011). Ecospirituality and public foreign language education: A critical discourse analysis of a transformative world language learning approach. Critical Inquiry in Language Studies, 8(1), 27-52. DOI: 10.1080/15427587.2011.545766.

[5] Gruenewald, D., \& Smith, G. A. (2008). Place-based education in the global age: local diversity. New York: Lawrence Erlbaum Associates, Taylor \& Francis Group.

[6] Hempton, G. (2014). One square inch: A sanctuary for silence at Olympic National Park http://onesquareinch.org/ (accessed 7/9/2017).

[7] Kaplan, S., Bardwell, L. V., \& Slakter, D. B. (1993). The restorative experience as a museum benefit. The Journal of Museum Education, 18(3), 15-18. DOI: Retrieved from http://www.jstor.org/stable/20715474 (accessed 12/11/2014).

[8] Kaplan, S. \& Berman, M. G. (2010). Directed attention as a common resource for executive functioning and self-regulation. Perspectives on Psychological Science, 5(1), 43-57. DOI: 10.1177/1745691609356784.

[9] Louv. R. (2005). Last child in the woods: Saving our children from nature-deficit disorder. Chapel Hill, NC: Algonquin Books of Chapel Hill.

[10] Louv, R. (2011). The nature principle: Human restoration and the end of nature-deficit disorder. Chapel Hill, NC: Algonquin Books of Chapel Hill.

[11] Lowenstein, E., Martusewicz, R., and Voelker, L. (2010, Fall). Developing teachers' capacity for EcoJustice Education and Community-based Learning. Teacher Education Quarterly, Fall, 99-188.

[12] McMurtrey, A. (Presenter). (1995, March). Paper presented at 45th Annual TESOL Convention: The world as classroom: Using excursions in intensive CBI courses. New Orleans, LA.

[13] Misiaszek, G. W. (2011). Ecopedagogy in the age of globalization: Educators' perspectives of environmental education programs in the Americas which incorporate social justice models (Doctoral dissertation). Retrieved from ERIC http://eric.ed.gov/?id=ED533850 (accessed 25/10/2014).

[14] Semken, S. \& Brandt, E. (2010). Implications of sense of place and place-based education for ecological integrity and cultural sustainability in diverse places. DOI: 10.1007/978-90-481-3929-3_24 (accessed 03/01/2014).

[15] Stone, L. (2002-2010). Q \& A: Continuous Partial Attention. [Blog]. Retrieved from http://lindastone.net/qa/continuous-partial-attention/ (accessed 12/11/2014).

[16] Williams, F. (2016, January). This is your brain on nature. National Geographic Magazine. Retrieved from http://www.nationalgeographic.com/magazine/2016/01/call-to-wild/ (accessed 22/11/2014).

[17] Williams, T. T. (1994). An unspoken hunger: Stories from the field. New York, NY: Pantheon Books. 
[18] Williams, T. (2017, April 20). Earth Day on Thursday's Access Utah [public radio broadcast interview with Tom Williams, Stephen Trimble, \& Jack Greene]. Retrieved from http://upr.org/post/earth-day-thursdays-access-utah (accessed 9/9/2017).

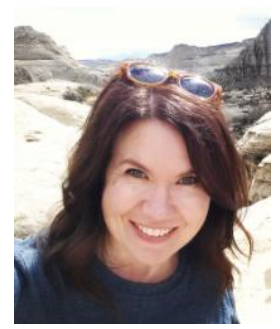

Kiri L. Manookin holds a M.Ed. in curriculum and instruction with an emphasis in English for Speakers of Others Languages (ESOL) from Concordia University - Portland, a B.S. in sociology from Brigham Young University, and a CELTA from International House Barcelona.

She currently teaches in the Department of English Language Learning at Utah Valley University. During her years there, she has enjoyed working with several other instructors to take students every semester on a four-day trip to beautiful Capitol Reef National Park and conducting a Wilderness Writing Workshop. She delights in watching students experience this geological phenomenon and the wonders of one of the darkest night skies in the United States. For several summers, she has also worked for the summer program at The American School in Switzerland (TASIS) teaching 14- to 18-year-olds. Additional work experience includes teaching English in Taiwan and Ecuador. She has authored several articles, including one about a Navajo rite of passage. Work from several of her writing students at UVU is expected in an upcoming anthology about Capitol Reef National Park (IN PRESS. The Capitol Reef Reader. Stephen Trimble, editor. University of Utah Press, Salt Lake City.)

Ms. Manookin was awarded the UVU Faculty Senate Award of Excellence in 2017. 